\title{
THE RELATIONSHIP BETWEEN GROUNDWATER AVAILABILITY AND DIABASE DIKES IN THE DEEP RIVER TRIASSIC BASIN, NORTH CAROLINA
}

STODDARD, Edward F., 5805 Contour Dr., Raleigh, NC 27612, skip.stoddard@gmail.com, CLARK, Timothy W., 3041 Granville Dr., Raleigh, NC 27609, KANE, Evan O., Wake County Department of Environmental Services, Raleigh, NC 27602, and BOLICH, Richard, Division of Water Resources, NC Department of Environmental Quality, Raleigh, NC 27699-1628

$\underline{\text { ABSTRACT }}$

Among geologists, extension agents, and well drillers, the Deep River Triassic basin is well known for its low groundwater yields. Poor sorting and high clay content of the basin's sedimentary rocks limit infiltration and lead to low hydraulic conductivity; wells drilled in older crystalline rocks outside the basin are usually much more successful. Further, Triassic soils are poorly suited for septic systems. Unless there is access to a public water supply and sewage system, the geologic boundary of the Triassic basin poses an impediment to residential and commercial development, as can be seen today in many rural areas, including northernmost Wake and southern Granville Counties.

For water wells in the basin, a preferred drilling target is a steeply dipping diabase dike. Dikes vary greatly in thickness, but even thin dikes can be good targets. Yields of 10 to $20 \mathrm{gpm}$ are common for wells in diabase, while wells in sedimentary rock seldom exceed 2 gpm, and many are dry holes.

Dikes can commonly be traced on the surface on the basis of spheroidally weathered residual cobbles an boulders. Larger dikes can be located on aeromagnetic maps, and even small ones can be mapped easily and in detail using ground magnetic surveys. Diabase outcrops typically exhibit strongly developed orthogonal joint systems. The higher yield of wells in diabase dikes has been variously tributed to jointing within the dikes, damming of ground water, or fractures in adjacent baked zones associated with higher yields.

Most diabase dikes are unmapped, as only the most obvious are shown on existing geologic maps. In the parts of the basin we have surveyed, we encounter at least one dike per $\mathrm{km}$ on a typical east-west traverse. Geophysical methods could be employed to great advantage in order to produce high quality, detailed maps showing dikes in areas under consideration for development. Such maps would also be useful in addressing important environmental questions, including the prediction of groundwater behavior at sites of proposed hydraulic fracturing or wastewater injection or irrigation.

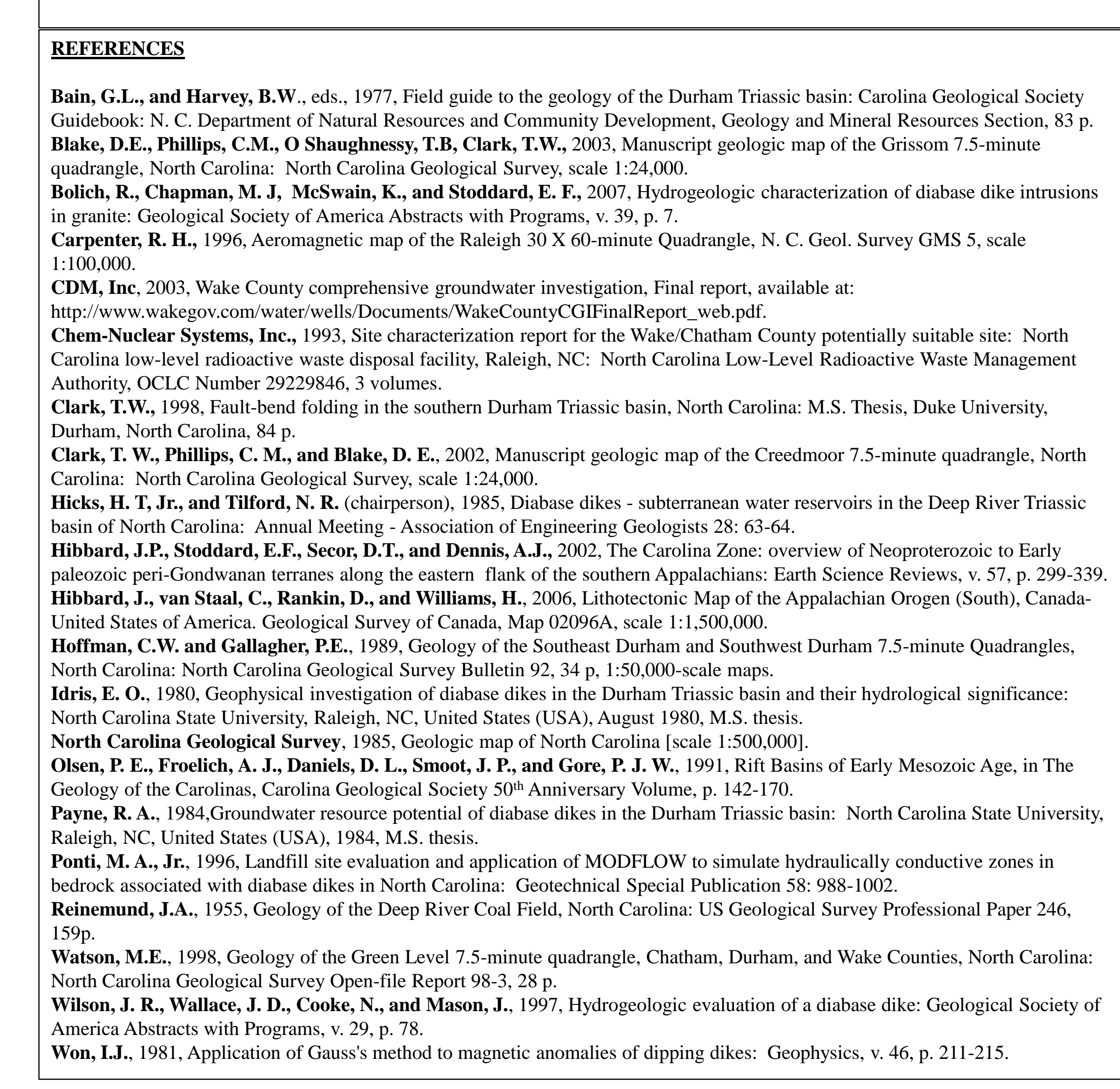

Geologic Setting

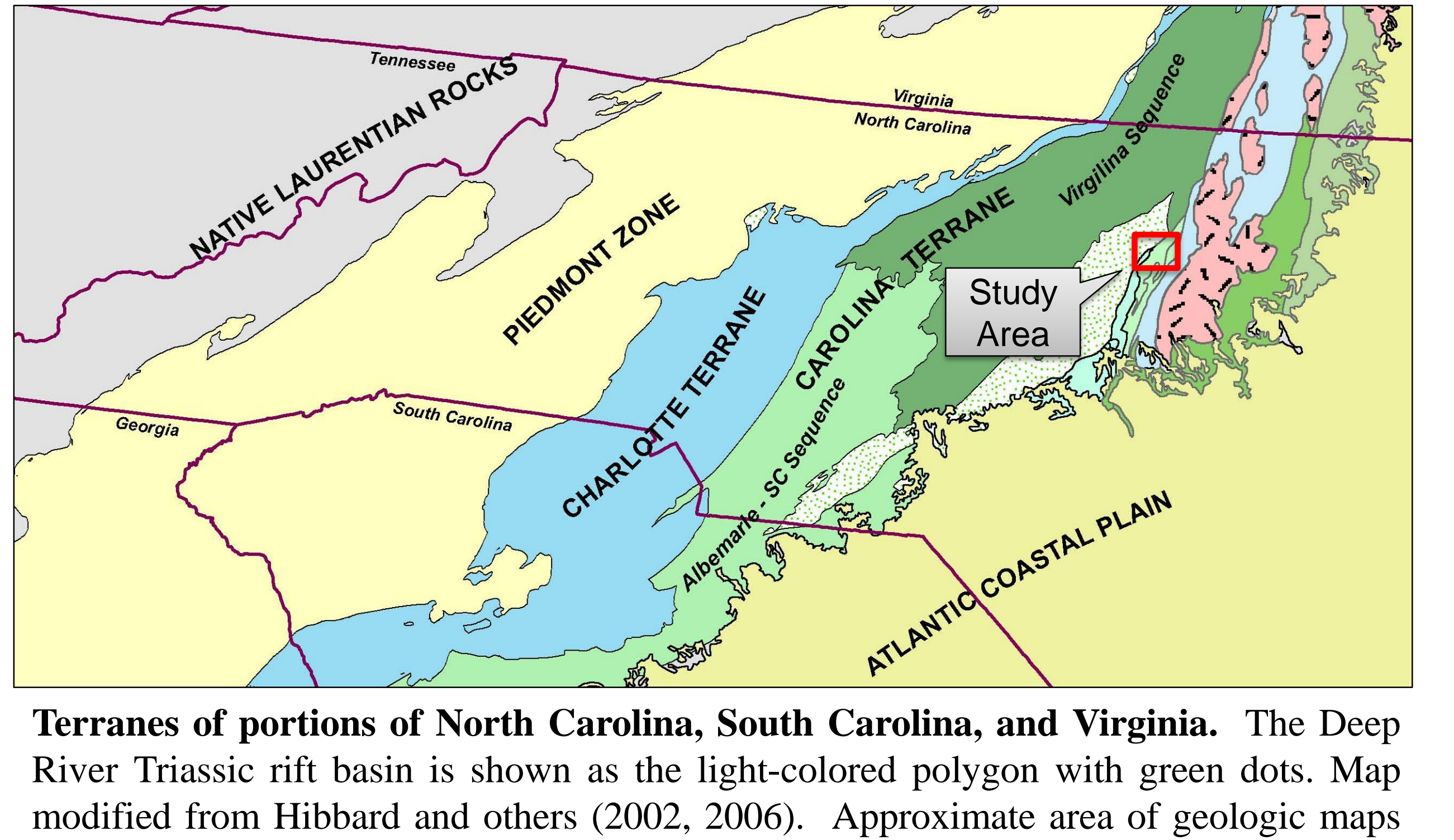

(2002, 2006). An

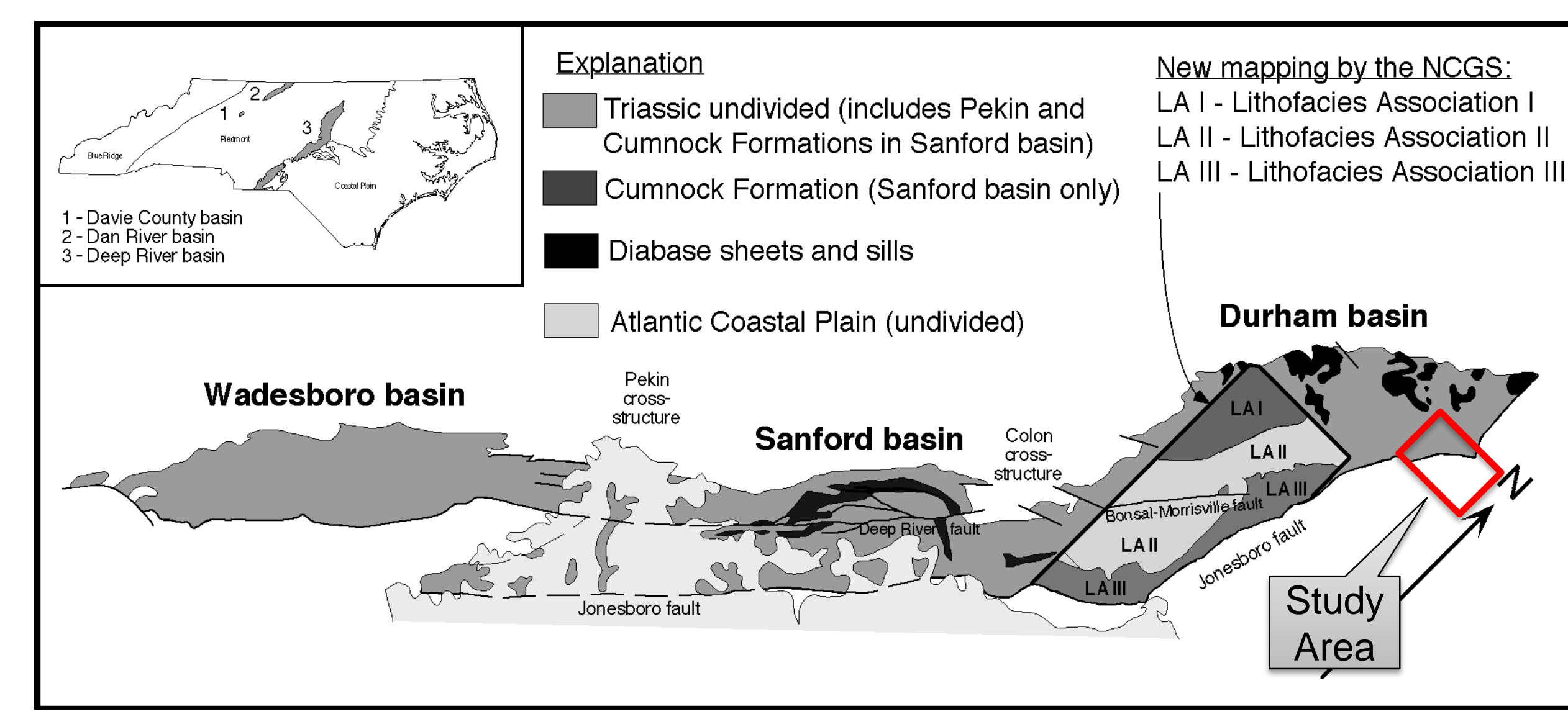

Generalized geologic map of the Deep River basin, NC. General distribution of scale, and their true abundance is greater than what is shown on available 7.5-minute
geological maps. Modified from Reinemund (1955), Bain and Harvey (1977), NCGS (1985), Olsen and others (1991), Hoffman and Gallagher (1989), Clark (1998), an

\section{Rock Types}

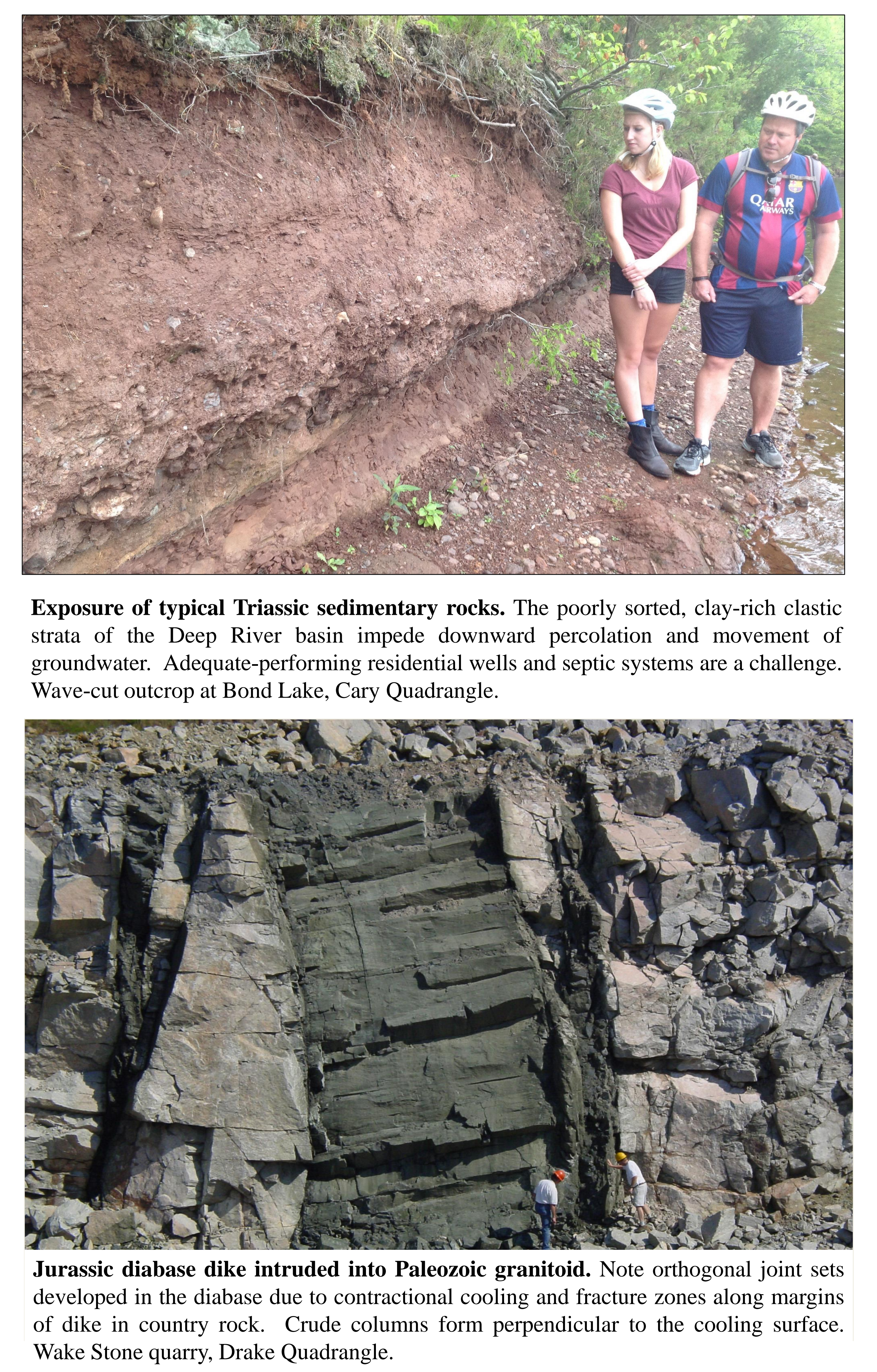

Field Expression of Diabase Dikes

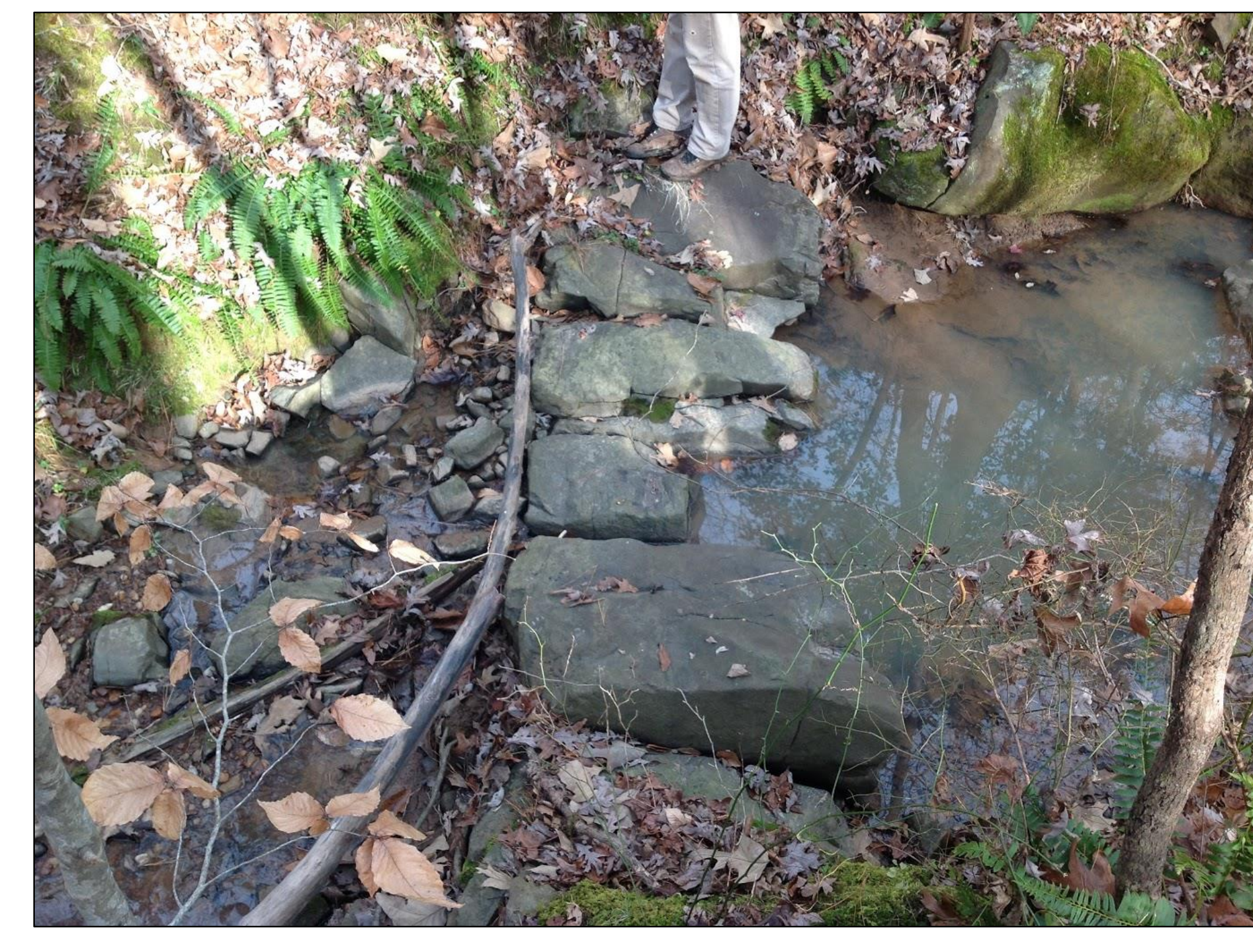

Natural creek outcrop of diabase dike. This dike displays both strike-parallel and strike-perpe

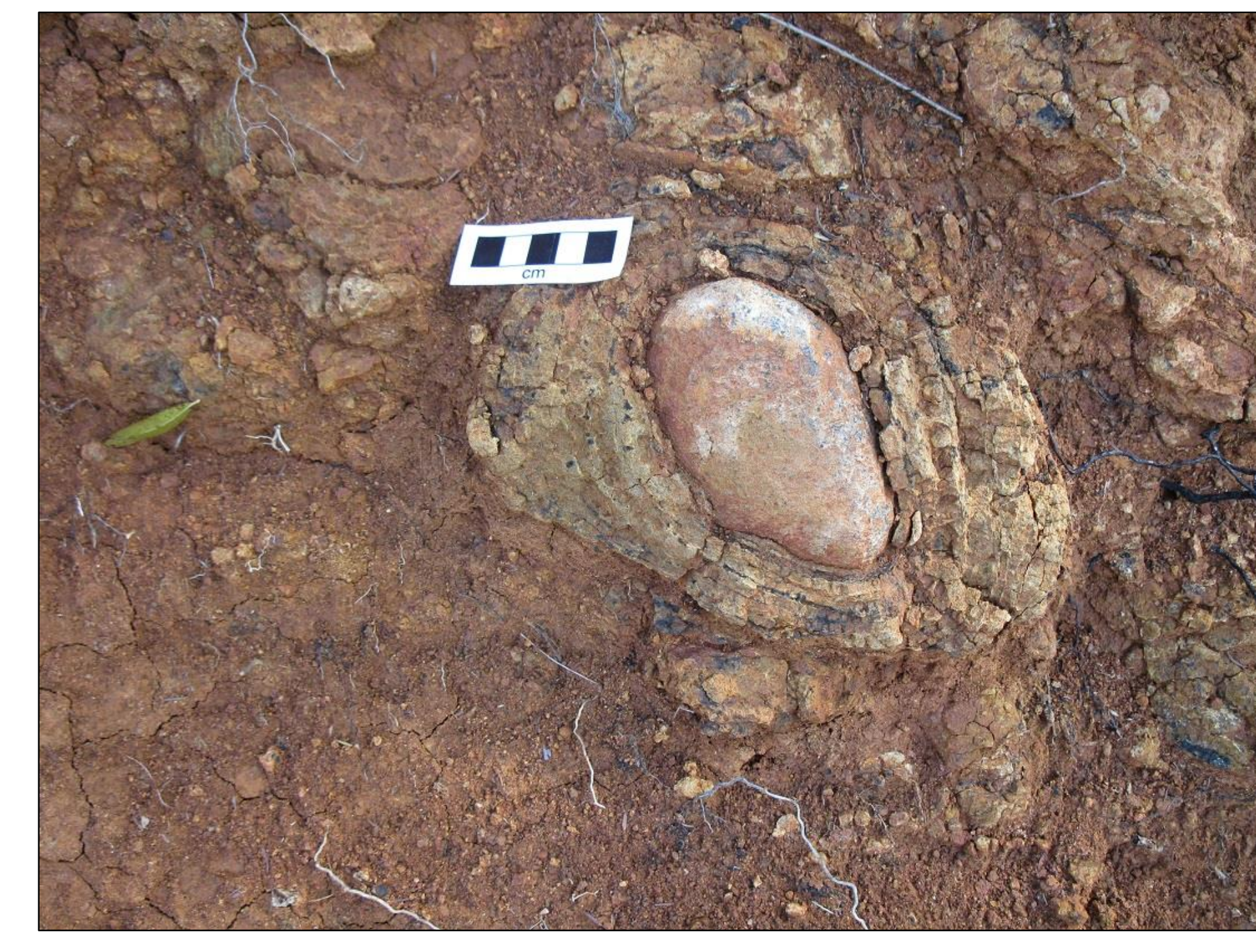

Spheroidal weathering of diabase dike. In-situ chemical
weathering of the jointed diabase results in the formation of concentric layers of "highly decayed saprolite surrounding a
competent and hard "core stone" of diabase. End result of this
coss is loose sheroidal cobbles and boulders. Shore of Falls Geologic Control on Land Use \&

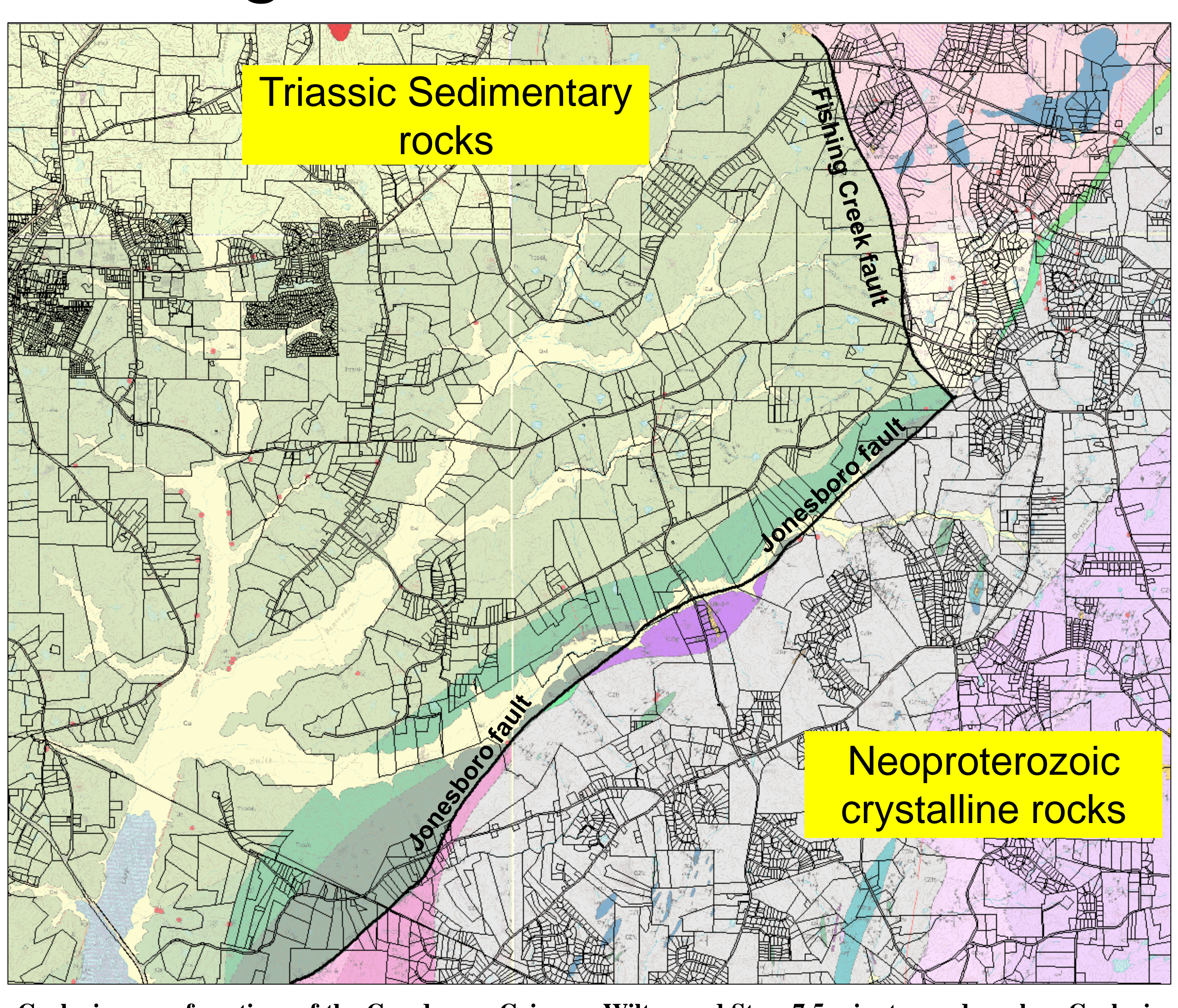

Geologic map of portions of the Creedmoor, Grissom, Wilton and Stem 7.5-minute quadrangles. Geologic
map is overlain by real estate parcel map. Triassic sedimentary units shown in green shades. Older boundary between the Triassicina and Neoproterozozic units is defined by the Jonsesboro and the Fishing creeks faults,
dip-slip normal faults related to the formation of the Deep River extension rift basin. The area of dense High groundwater yield in the Neoproterozoic rocks (typically 6-30 gpm) allows for higher density
Hocts subdivisions than are possible in the lower well yield areas of the Triassic sedimentary rocks $(0-5 \mathrm{gpm})$.
Furthermore, Triassic soils are poorly suited for septic systems. Unless there is access to a public water supply
and sewage system, the geologic boundary of the Triassic basin poses an impediment to residential and and sewage system, the geologic boundary of the Triassic basin poses an impediment to residential and
commercial development. This pattern of development hindered the growth of Cary, NC, until a public water

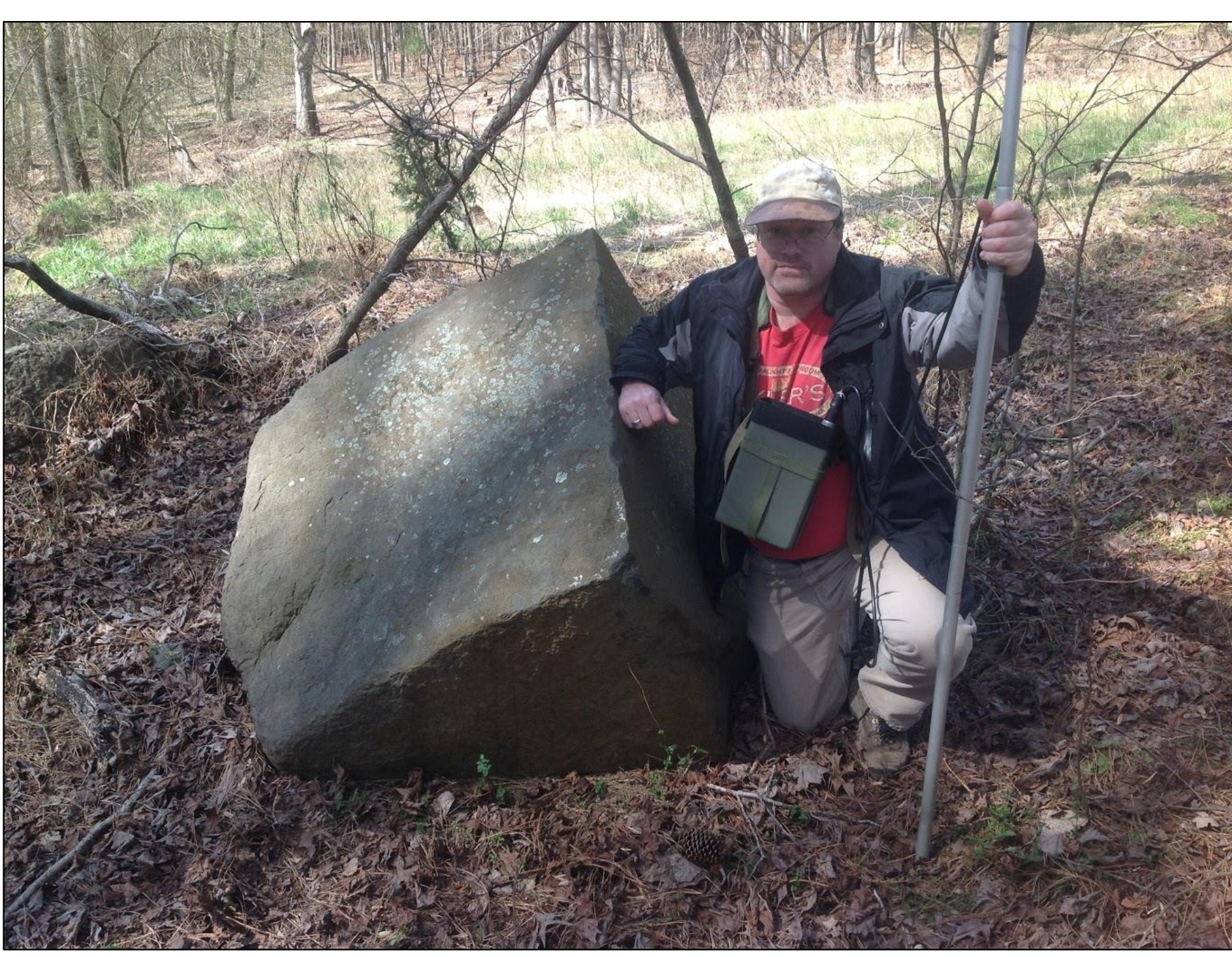

Large block of excavated diabase. Note orthogonal joint sets Grissom Quadrangle (see dike map to the right).

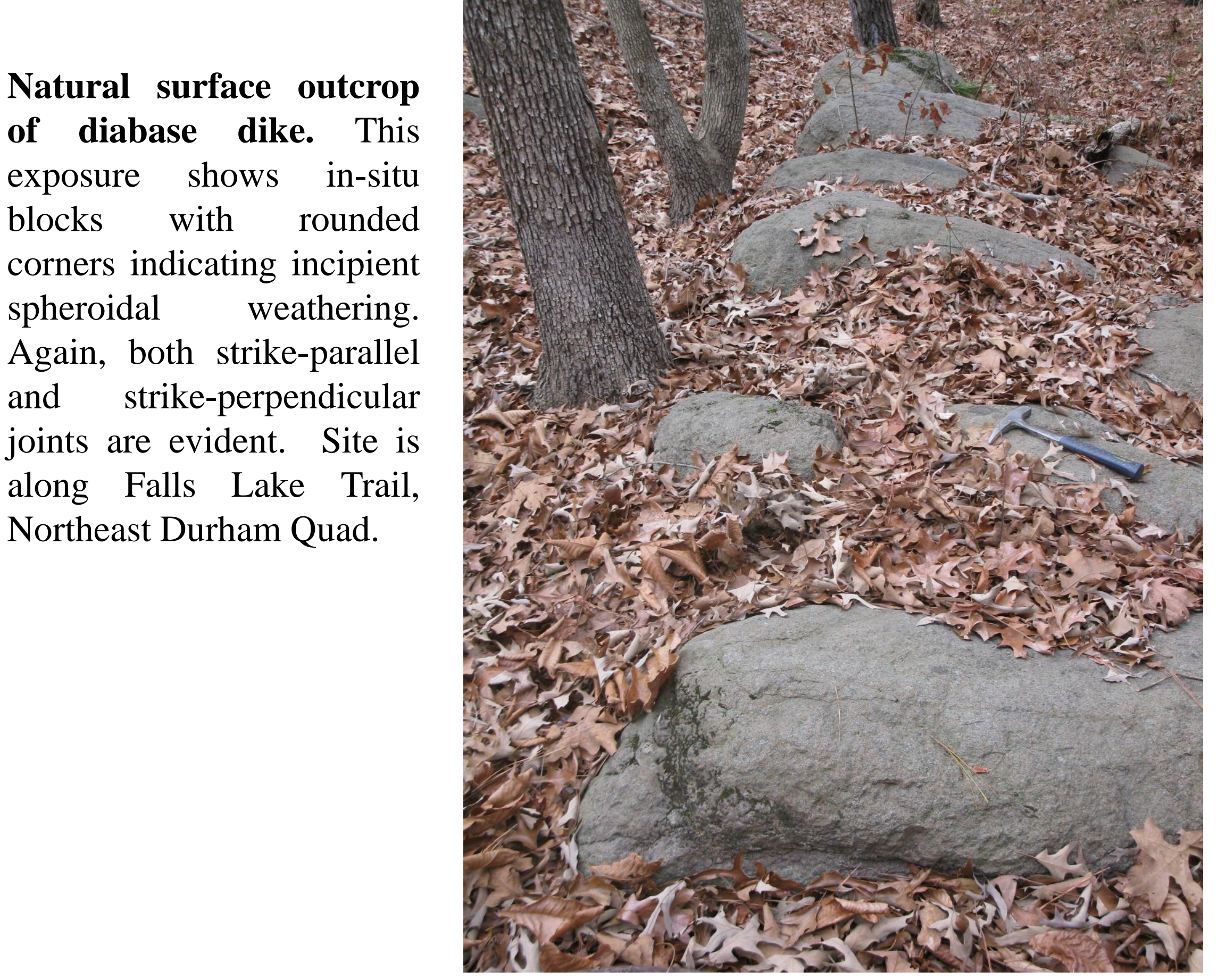

Development

RESIDENTIAL SUBDIVISIONS WITHOUT Southern Granvill ch

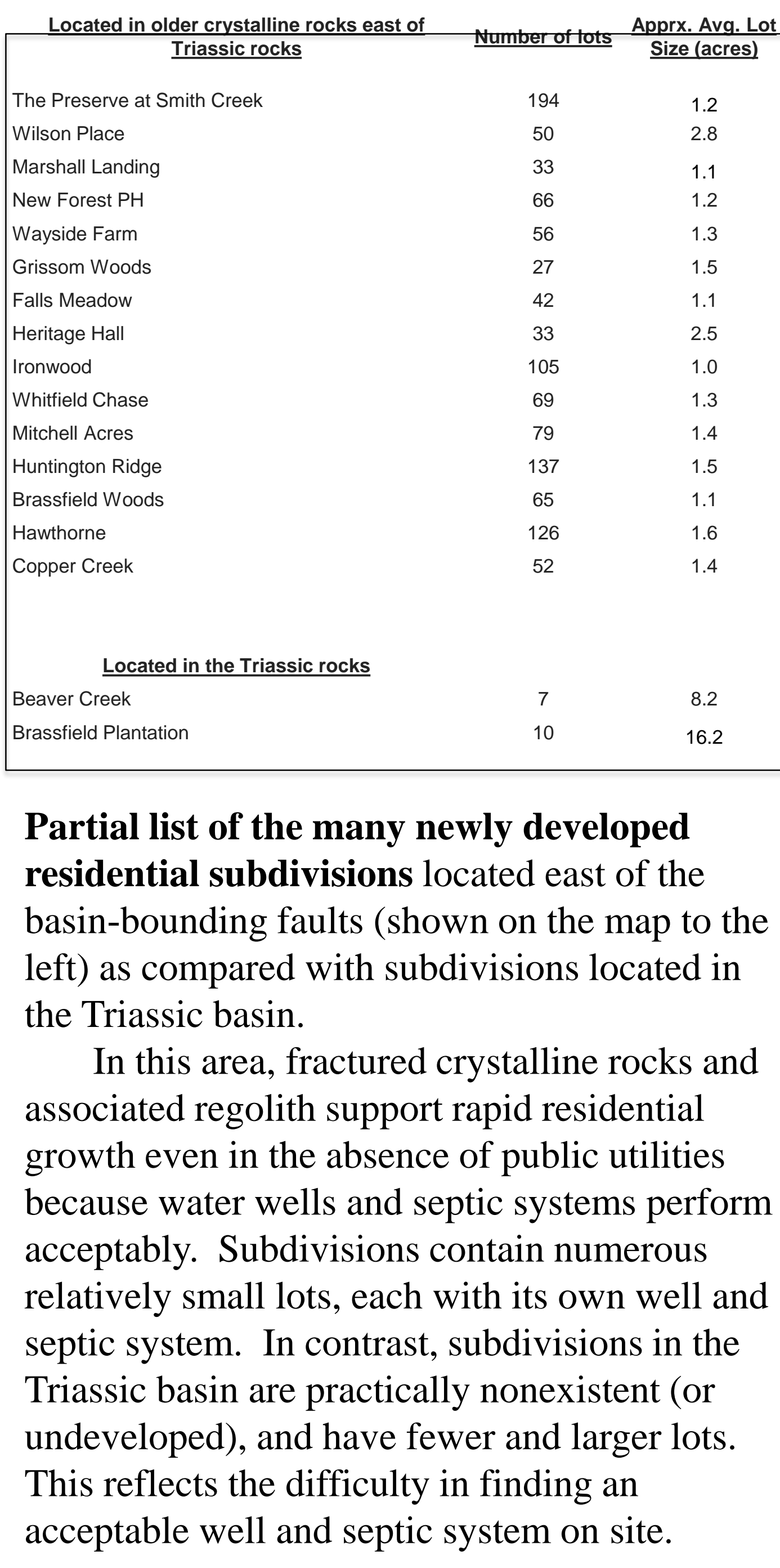

